Advance Journal of Food Science and Technology 5(9): 1153-1159, 2013

DOI:10.19026/ajfst.5.3074

ISSN: 2042-4868; e-ISSN: 2042-4876

(C) 2013 Maxwell Scientific Publication Corp.

Submitted: May 05, $2013 \quad$ Accepted: June 04, 2013

Published: September 05, 2013

\title{
Research Article \\ Bioactive Compounds of Palm Fatty Acid Distillate (PFAD) from Several Palm Oil Refineries
}

\author{
${ }^{1}$ Teti Estiasih, ${ }^{2}$ Kgs. Ahmadi, ${ }^{1}$ Tri Dewanti Widyaningsih, ${ }^{1}$ Jaya Mahar Maligan, ${ }^{1}$ Ahmad Zaki Mubarok, \\ ${ }^{1}$ Elok Zubaidah, ${ }^{1}$ Jhauharotul Mukhlisiyyah and ${ }^{1}$ Risma Puspitasari \\ ${ }^{1}$ Department of Food Science and Technology, Faculty of Agricultural Technology, Brawijaya University \\ Jl. Veteran, Malang, Jawa Timur, Indonesia 65145 \\ ${ }^{2}$ Department of Agroindustry Technology, Faculty of Agriculture, Tribhuwana Tunggadewi University Jl. \\ Telaga Warna, Tlogomas, Malang, Jawa Timur, Indonesia 6514
}

\begin{abstract}
This research studied the characteristics of Palm Fatty Acids Distillates (PFADs) from several palm oil refineries. It was aimed to know the potency of PFAD as bioactive compounds source, including vitamin E (mainly tocotrienols), phytosterols, squalene and possibly co-enzyme Q10 and polycosanol. Sampling was conducted at 6 palm oil refineries. The results showed that PFAD was dominated by free fatty acids of $85-95 \%$ with low oxidation level indicated by peroxide value of $1-10 \mathrm{meq} / \mathrm{kg}$ and anisidin value of 6-31. Bioactive compounds found were vitamin E 60-200 ppm, phytosterols 400-7500 ppm and squalene 400-2800 ppm, meanwhile polycosanol and coenzyme Q10 were not found. Vitamin E was dominated by tocotrienols and $\gamma$ tocotrienol was the major vitamin E, followed by $\alpha$ and $\delta$ tocotrienols. Phytosterols in PFADs from several palm oil refineries had variety in quantity and composition. Generally it was dominated by $\beta$ sitosterol, followed by stigmasterol and campesterol
\end{abstract}

Keywords: Co-enzyme Q10, palm fatty acid distillate, palm oil refinery, phytosterol, squalene, tocopherol, tocotrienol

\section{INTRODUCTION}

Palm oil is one of vegetable oils that rich in phytonutrients about $1 \%$, that comprises of vitamin $\mathrm{E}$ $(600-1000 \mathrm{ppm})$, carotenoid $(500-700 \mathrm{ppm})$, phytosterols (300-620 ppm), squalene (250-540 ppm), phospholipids (20-100 ppm), co-enzyme Q10 (10-80 ppm) and polyphenolics (40-70 ppm) (Loganathan et al., 2009). Palm oil refining steps to obtain edible oil are degumming to remove gum, bleaching to reduce color and deodorization. Deodorization is objected to remove volatile odoreous compounds and this process produces a by product that called Palm Fatty Acid Distillate (PFAD). The quantity of PFAD is about $4 \%$ from Crude Palm Oil (CPO) (Rakmi and Herawan, 2000 ) and about 3.66 ton PFAD is produced from every 100 tons of CPO (Chu et al., 2003). Commonly PFAD is used as fatty acids source for non food industries mainly oleochemical industries (Cheah et al., 2010) and this by-product is usually used for soap, feed and oleochemicals (Nang et al., 2009). PFAD contains fatty acids and glycerides of $96.1 \%$ and other minor bioactive compounds such as tocopherols and tocotrienols $(0.48 \%)$, phytosterols $(0.37 \%)$, squalene $(0.76 \%)$ and other hydrocarbons $(0.71 \%)$ (Gapoor et al., 2002), Unfortunately, PFAD has not been explored yet as bioactives source.

According to Liu et al. (2008), about $5-57 \%$ of tocopherols and tocotrienols is removed from CPO during deodorization and some of them is accumulated in PFAD that results PFAD with $0.7-1.0 \%$ of vitamin $\mathrm{E}$. Goh and Gee (1985) indicated that PFAD hydrocarbon was squalene as main components and minor component of n-alkane $\left(\mathrm{C}_{12} \mathrm{H}_{26}-\mathrm{C}_{36} \mathrm{H}_{74}\right)$. PFAD had higher quantity of squalene (up to $1.03 \%$ ) than other vegetable oils (Posada et al., 2007). Squalene has the ability to maintain healthy skin due to its antioxidant activity and protect skin from detrimental environmental effects (Nandi et al., 2008), as well as to reduce blood cholesterol level and anticancer (Loganathan et al., 2009). Newmark (1997) revealed that squalene had antitumor activity due to strong inhibiton of HMGCoA reductase that limit farnesyl pyrophosphate availability for oncogene prenylization thus inhibit oncogene relocation in cell membrane.

Palm oil has a slightly difference to other vegetable oil i.e., rich in tocotrienols and it is a source of tocotrienols beside rice bran oil (Puah et al., 2004). Vitamin E composition of palm oil is $\alpha$ tocopherol (20\%), $\alpha$ tocotrienol (22\%), $\gamma$ tocotrienol $(46 \%)$ and $\delta$ tocotrienol (12\%) (Ng et al., 2004; Puah et al., 2007).

\footnotetext{
Corresponding Author: Teti Estiasih, Department of Food Science and Technology, Faculty of Agricultural Technology, Brawijaya University J1. Veteran, Malang, Jawa Timur, Indonesia 65145

This work is licensed under a Creative Commons Attribution 4.0 International License (URL: http://creativecommons.org/licenses/by/4.0/).
} 
Tocotrienols are important for pharmaceutical, food, supplement products due to their activity as hypocholesterolaemic, antioxidant, antithrombotic, anti atherogenic, anti inflammatory, immunomodulator (Lewis, 2001) and hepatoprotector (Estiasih and Cholis, 2012).

Phytosterols of palm oil comprises of campesterol (13\%), $\beta$ sitosterol $(60 \%)$ and stigmasterol (24\%) (Loganathan et al., 2009). Phytosterols have capability to reduce blood cholesterol level by digestive absorption and their daily dose to get health benefits is 2-3 g (Taşan et al., 2006). Phytosterols also can stimulate breast milk production (Freitsche and Steinhart, 1999), as well as act as anti inflammatory, anticancer and immunomodulator (Carr et al., 2010).

Co-enzyme Q10, one of palm oil bioactive compounds, has similar structure to vitamin $\mathrm{E}$ and $\mathrm{K}$ but its antioxidant activity is ten fold higher than vitamin E. It is also known that co-enzyme Q10 has cardio-protective effect and anticancer (Loganathan et al., 2009). Other hydrocarbon of PFAD is supposed to be polycosanol. Polycosanol is a bioactive wax (Awika and Rooney, 2004) that capable to reduce blood cholesterol level by inhibition of cholesterol synthesis (Jain et al., 2007) and reducing HMG-CoA reductase activity (Somaiya et al., 2010).

So far, variational characteristics of PFAD as a byproduct of palm oil refineries have not been yet reported. Palm oil refineries might have different processing conditions that imply to different characteristics of PFAD, especially bioactive compounds. Therefore, this study was objected to know the characteristics of PFAD from several palm oil refineries.

\section{MATERIALS AND METHODS}

Materials: PFAD was obtained from 6 palm oil refineries at Java Island, Indonesia. Chemical reagents used were vitamin E standard ( $\alpha$ tocopherol, $\alpha$ tocotrienol, $\beta$ tocotrienol, $\delta$ tocotrienol), squalene, 1docosanol, phytosterol (campesterol, stigmasterol and $\beta$ sitosterol), MSTFA (methyl N-trimethylsilyltrifluoracetamide) (Santa Cruz Biotech USA), HPLC grade solvents (Merck) and other chemical reagents for analysis (Merck).

Characterization of PFAD: PFAD from 6 palm oil refineries were analyzed for oxidation level indicated by peroxide value (Hills and Thiel, 1946) and anisidine value (ISO, 2006), as well as free fatty acid content (AOCS, 1990). Bioactive compounds were analyzed as followed:

PFAD saponification: About $10 \mathrm{~g}$ of PFAD was put into $250 \mathrm{~mL}$ erlenmeyer with rubber seal and ethanol $88.3 \mathrm{~mL}, 0.5 \mathrm{~g}$ ascorbic acid and $5 \mathrm{~mL} \mathrm{KOH}$ solution
$(50 \% \mathrm{w} / \mathrm{v})$ were added. The mixture was stirred and heated at temperature of $65^{\circ} \mathrm{C}$ for $32 \mathrm{~min}$ on waterbath shaker. The reaction mixture was added by hexane 150 $\mathrm{mL}$ and distilled water $200 \mathrm{~mL}$ and then shaked slowly. The mixturer was let to separate on separating funnel for $\pm 1 \mathrm{~h}$ at ambient temperature. Aqueous lower layer contained saponifiable matters meanwhile upper hexane layer contained unsaponifiable matters. Hexane layer was evaporated by vacuum evaporator to obtain solvent free unsaponifiable fraction for further analysis.

Phytosterols analysis: Phytosterols analysis was followed method of Khatoon et al. (2010). About $1 \mathrm{mg}$ of unsaponifiable fraction of PFAD was added by ethanol $1 \mathrm{~mL}$ and subsequently filtered. $20 \mu \mathrm{L}$ of sample solution was injected into high performance liquid chromatography (Shimadzu LC20AT) with C18 PPODS column $250 \times 4.6 \mathrm{~mm}$ and uv vis detector (Shimadzu SPD20A) at wavelength of $206 \mathrm{~nm}$. Mobile phase was methanol: water (99:1 v: v) with flow rate of $1 \mathrm{~mL} / \mathrm{min}$. Identification and quantification was conducted by using phytosterols (stigmasterol, $\beta$ sitosterol, campesterol) standard that injected into HPLC separately.

Vitamin E analysis: This procedure was according to Ball (1988). About $1 \mathrm{mg}$ of unsaponifiable fraction of PFAD was added by ethanol $1 \mathrm{~mL}$ and then filtered. 20 $\mu \mathrm{L}$ of sample solution was injected into high performance liquid chromatography (Shimadzu LC20AT) with C18 PPODS column $250 \times 4.6 \mathrm{~mm}$ and uv vis detector (Shimadzu SPD20A) at wavelength of $295 \mathrm{~nm}$. Mobile phase was methanol: water (95:5 v: v) with flow rate of $1 \mathrm{~mL} / \mathrm{min}$. Identification and quantification was conducted by using $\alpha$ tocopherol, $\alpha$ tocotrienol, $\beta$ tocotrienol, $\delta$ tocotrienol and $\gamma$ tocotrienol standards that injected into HPLC separately.

Polycosanol and squalene analysis: This analysis was using GC MS with derivatization method according to Mendez et al. (2003) by using MSTFA. About $10 \mathrm{mg}$ of unsaponifiable fraction of PFAD was put into reaction tube and added by MSTFA $10 \mu \mathrm{L}$. The mixture was heated at $60^{\circ} \mathrm{C}$ for $15 \mathrm{~min}$. External standard of 1 docosanol was used for quantification that prepared by diluting $1 \mathrm{mg}$ of this standard with MSTFA $100 \mu \mathrm{L}$ and the mixture was heated at $60^{\circ} \mathrm{C}$ for $15 \mathrm{~min}$.

$1 \mu \mathrm{L}$ of derivatized sample was injected into GC MS (GCMS-QP2010S Shimadzu) (with column (AGILENT DB-1) $30 \mathrm{~m}$, i.d. $0.25 \mathrm{~mm}$, helium as carrier gas and ionization EI $70 \mathrm{Ev}$. GC operational condition was column oven temperature of $80^{\circ} \mathrm{C}$, injector temperature of $310^{\circ} \mathrm{C}$, pressure of $16.5 \mathrm{kPa}$, total flow rate of $80.0 \mathrm{~mL} / \mathrm{min}$, column flow rate of $0.50 \mathrm{~mL} / \mathrm{min}$, linear velocity of $26.1 \mathrm{~cm} / \mathrm{s}$, suooorting gas rate of $3.0 \mathrm{ml} / \mathrm{min}$ and split ratio of 153.0 . Initial temperature was $80^{\circ} \mathrm{C}$ and holded for $5 \mathrm{~min}$. 
Temperature was increased with rate of $10^{\circ} \mathrm{C} / \mathrm{min}$ to the temperature of $305^{\circ} \mathrm{C}$ and holded for $25 \mathrm{~min}$. MS analysis was conducted at ion source temperature of $250^{\circ} \mathrm{C}$, interface temperature of $310^{\circ} \mathrm{C}$, solvent cut time of $4.80 \mathrm{~min}$, scan speed of 1250 , start $\mathrm{m} / \mathrm{z} 28.0$ and end $\mathrm{m} / \mathrm{z} 600.0$.

Co-enzyme Q10 analysis: Co-enzyme Q10 analysis was refered to method of Mahendra et al. (2011). About $1 \mathrm{mg}$ of unsaponifiable fraction of PFAD was diluted with acetone $1 \mu \mathrm{mL}$. $20 \mu \mathrm{L}$ of sample solution was injected into (Shimadzu LC20AT) with C8 column $250 \times 4.6 \mathrm{~mm}$ and uv vis detector (Shimadzu SPD20A) with mobile phase acetonitrile: isopropanol $(86: 14 \mathrm{v}: \mathrm{v})$. Analysis was performed in isocratic condition at column temperature of $50^{\circ} \mathrm{C}$, flow rate of $1.0 \mathrm{~mL} / \mathrm{min}$ and using uv vis detector (Shimadzu SPD20A) at wave length of $210 \mathrm{~nm}$.

\section{RESULTS AND DISCUSSION}

PFAD chemical characteristics: PFADs from several palm oil refineries had slightly different oxidation level and free fatty acid content (Table 1) in the range of 85 $93 \%$. Free fatty acids level was in accordance to PORIM standard for PFAD that free fatty acid content should be minimum 70\% (Affandi, 1994). Different deodorization process applied in palm oil refineries might lead to different free fatty acid content of PFAD, but we had no data of deodorization and other refining process from these 6 palm oil refineries. Ceriani and Mirelles (2004) showed that different deodorization temperature and pressure in canola, wheat and soybean oil processing had different deodorizer distillate composition indicated by different concentration of Triglycerides (TG), Diglycerides (DG), Monoglycerides (MG) and Free Fatty Acids (FFA), as well as bioactive compounds such as squalene, $\delta$ tocopherol and $\beta$ sitosterol.

Ceriani and Mirelles (2004) revealed that different temperature $\left(240-260^{\circ} \mathrm{C}\right)$ and pressure $(1-6 \mathrm{mmHg})$ during continuous deodorization of soybean oil produced Soybean Oil Deodorizer Distillate (SODD) with free fatty acids content of $8-65 \%$. Increasing deodorization temperature caused increasing non free fatty acids components such as TG, DG, tocopherol and $\beta$ sitosterol, thus decreasing free fatty acids content. Conversely, increasing deodorization pressure led to decreasing TG, DG, tocopherol and $\beta$ sitosterol thus increased free fatty acid content. Therefore, variation in free fatty acids content of PFADs from several palm oil refineries possibly related to variation in deodorization process parameters as well as characteristics of $\mathrm{CPO}$ as input materials.

Oxidation level of PFADs also varied that indicated by peroxide value as indicator of primary oxidation products and anisidine value as indicator of secondary oxidation products. Deodorization is aimed to remove odoreous volatile compounds including products of secondary oxidation. Data in Table 1 showed that oxidation level of PFADs was quite low with peroxide value of 1-9 meq $/ \mathrm{kg}$ and anisidine value of 6-31. Benites et al. (2009) showed that a deodorizer distillate of soybean oil had peroxide value of 7.5 $\mathrm{meq} / \mathrm{kg}$ and TBA value of $16.0 \mathrm{mg} \mathrm{MDA} / \mathrm{kg}$. Oxidation products are volatile and vaporize during deodorization. Perhaps, only small amount of oxidation products were condensed during distillation for free fatty acids recovery. Deodorizer distillate was the product of low temperature condensation of vaporized components in CPO. High condensation temperature components might not capable to change into liquid and was not recovered in PFAD. Thus, low oxidation level of PFADs was due to not all of oxidation products condensed.

Data in Table 1 showed that unsaponifiable matters of PFADs was $0.5-4 \%$ and saponiafiable matters was 96-99\%, and PORIM standard required minimum saponifibale matters of $95 \%$ (Affandi, 1994). Variation of usaponifiable matters of PFADs was possibly due to variation in processing conditions such as degumming, bleaching and deodorization, as well as raw material variability. Unsaponifiable matters of PFAD were supposed to contain bioactive compounds.

Bioactive compounds of PFADs: Bioactive compounds PFADs were vitamin E, phytosterols and squalene, meanwhile polycosanol and co-enzyme Q10 were not detected (Table 2). Vitamin E concentration of PFADs was 60-280 ppm; phytosterol content was 400$7500 \mathrm{ppm}$ and squalene concentration of 400-3000 ppm. Loganathan et al. (2009) revealed that palm oil had vitamin E 600-1000 ppm, phytosterols 300-620 ppm, carotenoid 500-700 ppm, squalene $250-540 \mathrm{ppm}$, phospholipids 20-100 ppm, co-enzyme Q10 10-80 ppm and polyphenols $40-70 \mathrm{ppm}$.

PFADs from several palm oil refineries had variation in composition and concentration of bioactive compounds. Ceriani and Mirelles (2004) showed that deodorizer distillate of soybean oil contained squalene, tocopherol and $\beta$ sitosterol; wheat oil contained tocopherol; and canola oil contained $\beta$ sitosterol and tocopherol. Benites et al. (2009) also showed that deodorizer distillate of soybean oil contained tocopherol. Meanwhile, Khatoon et al. (2010) showed that deodorizer distillate of soybean oil contained phytosterol. Bondioli et al. (1993) revealed that deodorizer distillate of olive oil contained squalene. Furthermore, Winkle-Moser and Vaughn (2009) indicated that deodorizer distillers of dried grain oils contained phytosterol, steryl ferulat, tocopherol, tocotrienol and carotenoid.

Data in Table 2 showed that bioactive compounds of PFADs from several palm oil refineries were very vary. There was a correlation between bioactive compounds content with unsaponifiable matters. Palm oil refinery 2 had low unsaponifiable matters thus also 
Adv. J. Food Sci. Technol., 5(9): 1153-1159, 2013

Table 1: PFAD characteristics from several palm oil refineries

\begin{tabular}{llllll}
\hline & \multicolumn{3}{c}{ Oxidation level } & & \\
Palm oil refinery & Free fatty acids (\%) & Peroxide value (meq/kg) & Anisidine value & $\begin{array}{l}\text { Unsaponifiable } \\
\text { matters (\%) }\end{array}$ & $\begin{array}{l}\text { Saponifiable matters } \\
(\%)\end{array}$ \\
\hline 1 & 87.83 & 1.53 & 6.92 & 2.20 & 97.80 \\
2 & 90.59 & 3.22 & 30.79 & 0.67 & 99.33 \\
3 & 88.53 & 8.61 & 15.78 & 3.98 & 96.02 \\
4 & 92.93 & 5.31 & 22.41 & 3.20 & 96.80 \\
5 & 90.45 & 3.09 & 10.77 & 2.20 & 97.80 \\
6 & 85.42 & 9.17 & 17.44 & 2.30 & 97.70 \\
\hline
\end{tabular}

Table 2: Bioactive compounds of PFADs from several palm oil refineries

\begin{tabular}{llllll}
\hline Palm oil refinery & Vitamin E $(\mathrm{ppm})$ & Phytosterol $(\mathrm{ppm})$ & Squalene $(\mathrm{ppm})$ & Polycosanol $(\mathrm{ppm})$ & Co-enzyme Q10 $(\mathrm{ppm})$ \\
\hline 1 & 195.60 & 7476.56 & 2373.27 & nd & nd \\
2 & 64.70 & 407.00 & 462.87 & nd & nd \\
3 & 280.63 & 6011.72 & 2767.08 & nd & nd \\
4 & 200.76 & 2310.52 & 1380.16 & nd & nd \\
5 & 172.47 & 1956.15 & 2222.41 & nd & nd \\
6 & 208.82 & 3915.22 & nd & nd & nd \\
\hline
\end{tabular}

had low concentration of bioactive compounds. All PFADs had vitamin $\mathrm{E}$ and phytosterols, but squalene was not detected in PFAD from palm oil refinery 6. Beside variation in $\mathrm{CPO}$ caharacteristics and refining process, handling and extraction in palm milling industries to produce $\mathrm{CPO}$ might also affect variability in composition and concentration of PFAD bioactive compounds.

Generally, phytosterols were predominant bioactive compounds of PFAD. The major bioactive compounds in deodorizer distillates of vegetable oils were vary, such as phytosterols in soybean oil (Khatoon et al., 2010) and canola oil, tocopherol in wheat oil (Ceriani dan Mirelles, 2004) and squalene in olive oil (Bondioli et al., 1993). Compared to other deodorizer distillates, tocopherol concentration in wheat oil deodorizer distillate was $0.246 \%$ or $2460 \mathrm{ppm}$ and in soybean oil was $\pm 1000 \mathrm{ppm}$ (Ceriani and Mirelles, 2004), meanwhile PFAD contained vitamin E of 60-280 ppm. Phytosterols concentration in soybean oil deodorizer distillate was $6-10 \%$ or $60000-100000 \mathrm{ppm}$ (Khatoon et al., 2010), meanwhile PFAD had phytosterols of 400-7500 ppm. Bondioli et al. (1993) showed that squalene content of olive oil deodorizer distillate was $10-30 \%$ or $10000-30000 \mathrm{ppm}$, meanwhile PFADs had squalene of 400-3000 ppm. It is important to note that PFADs had more complete bioactive compounds that contained vitamin E (especially tocotrienols), phytosterols and squalene. Lower bioactive compounds content of PFADs than other vegetable oil deodorizer distillates was due to lower unsaponifiable fraction of PFADs. Benites et al. (2009) reported that free fatty acids in distillate deodorizer of soybean oil was $53 \%$, meanwhile PFADs had free fatty acids of $85-93 \%$.

Polycosanol was not detected in PFADs. This compound was categorized as primary aliphatic long chain alcohol with high molecular weight and atom $\mathrm{C}$ number of 20-39 that comprised of 1-octacosanol (C28), 1-triacontanol (C-30), 1-docosanol (C-22), 1- tetracosanol (C-24), 1-hexacosanol (C-26), 1heptacosanol (C-27), 1-nonacosanol (C-29), 1dotriacontanol (C-32) and 1-tetracontanol (C-34) (Prakash and DuBois, 2007; Somaiya et al., 2010). Polycosanol was a natural compound that usually found in wax such as sugar cane, rice husk and bees wax (Kassis, 2008). The presence of polycosanol in palm fruit exocarp and mesocarp has not been reported yet and this study showed that polycosanol was not found in PFADs.

Co-enzyme Q10 or ubiquinone also was not detected in PFADs. Co-enzyme Q10 was found in palm oil in low concentration of $10-80 \mathrm{ppm}$ and this compound had 10 fold higher antioxidant activity compared to vitamin E, involved in ATP or energy synthesis, acted as anticancer and had heart protective effect (Loganathan et al., 2009). Perhaps, due to its low concentration in palm oil and low volatility, co-enzyme Q10 was not detected in PFAD.

Vitamin E composition: The superiority of PFADs over other deodorizer distillates was the presence of tocotrienols as predominat vitamin E. Tocotrienols were found in high concentration in palm oil and rice bran (Theriault et al., 1999), meanwhile other vitamin $\mathrm{E}$ sources such as coconut, soybean, cacao, barley, wheat germ, sunflower, groundnut, walnut, sesame and olive oils only contained tocopherols (Heinonen and Piironen, 1991). Tocotrienols have been reported to have more advantages over tocopherols due to their higher capability in inhibiting microsome and liver mitochondria peroxidation as well as dioleoylphosphatidylcholine liposomes oxidation (Serbinova and Packer, 1994; Packer et al., 2001). Deodorizer distillate of soybean oil only contained tocopherols meanwhile tocotrienols were not found (Wan et al., 2008).

Palm oil contained several vitamin $\mathrm{E}$ isomers, i.e., $\alpha$ tocopherol, $\alpha$ tocotrienol, $\gamma$ tocopherol, $\gamma$ tocotrienol and $\delta$ tocotrienol $(\mathrm{Ng}$ et al., 2004) with vitamin $\mathrm{E}$ concentration of 600-1000 ppm. Puah et al. (2004) 
Table 3: Vitamin E profile of PFADs from several palm oil refineries

\begin{tabular}{llllll}
\hline $\begin{array}{l}\text { Palm oil } \\
\text { refinery }\end{array}$ & $\alpha \mathrm{T} 3(\%)$ & $\begin{array}{l}\delta \mathrm{T} 3 \\
(\%)\end{array}$ & $\begin{array}{l}\gamma \mathrm{T} 3 \\
(\%)\end{array}$ & $\begin{array}{l}\alpha \mathrm{T} \\
(\%)\end{array}$ & $\begin{array}{l}\text { Total } \\
\mathrm{T} 3(\%)\end{array}$ \\
\hline 1 & 18.31 & 2.32 & 60.04 & 19.33 & 80.67 \\
2 & 18.50 & 18.62 & 49.74 & 13.14 & 86.86 \\
3 & 6.19 & 9.70 & 36.13 & 47.97 & 52.03 \\
4 & 18.47 & 31.70 & 41.86 & 7.96 & 92.04 \\
5 & 16.80 & 15.95 & 50.08 & 17.17 & 82.83 \\
6 & 24.72 & 6.77 & 35.15 & 33.36 & 66.64 \\
\hline \multicolumn{5}{r}{ Tocopherol, T3 }
\end{tabular}

Table 4: Phytosterol profile of PFADs from several palm oil refineries

\begin{tabular}{llll}
\hline $\begin{array}{l}\text { Palm oil } \\
\text { refinery }\end{array}$ & $\begin{array}{l}\text { Beta sitosterol } \\
(\%)\end{array}$ & Stigmasterol (\%) & $\begin{array}{l}\text { Campesterol } \\
(\%)\end{array}$ \\
\hline 1 & 52.34 & 23.92 & 23.74 \\
2 & 93.75 & 4.05 & 2.20 \\
3 & 45.63 & 25.75 & 28.62 \\
4 & 65.91 & 25.68 & 8.40 \\
5 & 91.58 & 0.56 & 7.85 \\
6 & 91.34 & nd & 8.66 \\
\hline
\end{tabular}

reported that vitamin $\mathrm{E}$ composition of palm oil was $\alpha$ tocopherol $(20 \%), \alpha$ tocotrienol $(22 \%), \gamma$ tocotrienol $(46 \%)$ and $\delta$ tocotrienol (12\%). Data in Table 3 showed that tocotrienols were predominant vitamin $\mathrm{E}$ in PFADs from several palm oil refineries with proportion of 50$92 \%$ based on total vitamin E. This study revealed that tocotrienols concentration of PFADs from several palm oil refineries varied due to the influence of palm fruit characteristics, CPO extraction and handling, as well as refining process. The predominant vitamin $\mathrm{E}$ of PFADs was $\gamma$ tocotrienol. The result of this study was in accordance to that reported by Puah et al. (2004) that vitamin $\mathrm{E}$ in palm oil was dominated by $\gamma$ tocotrienol. Generally, tocotrienols concentration in PFADs was in order of $\gamma>\delta>\alpha$ tocotrienol.

Phytosterols composition: Phytosterols were predominat bioactive compounds of PFADs (Table 2). Khatoon et al. (2010) reported that phytosterols and vitamin $\mathrm{E}$ was found in unsaponifiable fraction of soybean oil deodorizer distillate and free fatty acids were the major component. Data in Table 4 showed that $\beta$ sitosterol was predominat phytosterols in PFADs from several palm oil refineries. The composition of each phytosterols compound ( $\beta$ sitosterol, campesterol and stigmasterol) varied among PFADs. Campesterol was detected in all PFADs meanwhile stigmasterol was not detected in PFAD from palm oil refinery 6 . Loganathan et al. (2009) reported that phytosterols of palm oil comprised of campesterol (13\%), $\beta$ sitosterol $(60 \%)$ and stigmasterol (24\%). Phytosterols had ability to reduce blood cholesterol level, anti thrombotic and anticancer (Awad and Fink, 2000; Piiron et al., 2000, Ostlund et al., 2002). Phytosterols from PFADs could be extracted to have phytosterol enrich fraction that could be used as food supplement for related diseases prevention.

It was interesting that palm oil refineries 1 and 5 were from one company but different location and showed different phytosterol composition. Although we did not have data about refining conditions especially deodorization, we supposed that both palm oil refineries applied similar processing parameters. The variability of phytosterols composition was supposed due to variability in CPO characteristics. Both palm oil refineries used same CPO source but different distance from palm milling industry to refineries.

\section{CONCLUSION}

PFADs from several palm oil refineries had variability in characterisctis. PFAD was dominated by free fatty acids with low level of primary and secondary oxidation products. Bioactive compounds of PFADs were phytosterols, vitamin $\mathrm{E}$ and squalene with variational concentration and composition. Generally, vitamin $\mathrm{E}$ was dominated by $\gamma$ tocotrienol meanwhile predominat phytosterol was $\beta$ sitosterol. The common concentration of tocotrienol was in order of $\gamma>\alpha>\delta$ tocotrienol, meanwhile phytosterol was in order of $\beta$ sitosterol $>$ stigmasterol $>$ campesterol.

\section{ACKNOWLEDGMENT}

We are very grateful to Directorate General of Higher Education, Ministry of Education and Culture, Republic of Indonesia for funding this research through MP3EI grant with contract no. 225/SP2H/PL/ Dit.Litabmas/V/2012, May 23, 2012.

\section{REFERENCES}

Affandi, M.S.Y., 1994. Refining and downstreaming processing of palm and palm kernel oils: Processing of palm and palm kernel oils. In Selected Readings on Palm Oil and Its Uses Edited by Technical Commitee of 1995 Palm Oil Familiarization Programme, Palm Oil Research Institute of Malaysia, Kuala Lumpur, pp: 35-59.

AOCS, 1990. Official Methods and Recommended Practices of the American Oil Chemistry Society. 4th (Ed.), Broadmaker Drive, Champaign, Illinois.

Awad, A.B. and C.S. Fink, 2000. Phytosterol as anticancer dietary component: Evidence and mechanism of action. J. Nutr., 130: 2127-2130.

Awika, J.M. and L.W. Rooney, 2004. Sorghum phytochemicals and their potential impact on human health. Phytochemistry, 65: 1199-1221.

Ball, G.F.M., 1988. Fat-Soluble Vitamin Assays in Food Analysis (A Comprehensive Review). Elsivier Applied Science, London.

Benites, C.I., V.O.C. Chonca, S.M.P.M. Reis and O.C. De Oliveirra, 2009. Physiochemical characterization of soybean oil deodorizer distillate. Chem. Eng.Trans., 17: 903-908.

Bondioli, P., C. Mariani, A. Lanzani, E. Fedeli and A. Muller, 1993. Squalene recovery from olive oil deodorizer distillates. J. Am. Oil Chem. Soc., 70(8): 763. 
Carr, T.P., M.M. Ash and A.W. Brown, 2010. Cholesterol-lowering phytosterols: Factors affecting their use and efficacy. Nut. Dietary Suppl., 2: 59-72.

Ceriani, R. and A.J.A. Meirelles, 2004. Simulation of continuous deodorizer: Effects on product streams. J. Am. Oil Chem. Soc., 81(11): 1059-1069.

Cheah, K.Y., T.S. Toh and P.M. Koh, 2010. Palm Fatty Acid Distillate Biodiesel: Next Generation Palm Biodiesel. Inform, AOCS.

Chu, B.S., S.Y. Quek and B.S. Baharin, 2003. Optimisation of enzymatic hydrolysis for concentration of vitamin $\mathrm{E}$ in palm fatty acid distillate. J. Food Chem., 80(3): 295-302.

Estiasih, T. and M.N. Cholis, 2012. Hepatoprotective effect of tocotrienol rich fraction from palm fatty acid distillate on highly oxidized frying oil induced peroxidation rats. Research Report of IMHERE Research Grant, Research Center, Brawijaya University.

Gapoor, A., W.H.W. Hassan and M. Sulong, 2002. Phytochemical for nutraceutical from the by product of palm oil refining. Palm Oil Develop., 36: 13-19.

Goh, S.H. and P.T. Gee, 1985. Noncarotenoids hydrocarbon in palm oil and palm fatty acid distillate. J. Am. Oil Chem. Soc., 63(2): 226-230.

Heinonen, M. and V. Piironen, 1991. The tocotrienol and vitamin $\mathrm{E}$ content of the average Finnish diet. Int. J. Vitam. Nutr. Res., 61(1): 27-32.

Hills, G. and C.C. Thiel, 1946. The frric thyocyanate method of estimating peroxide in the fat of butter, milk and dried milk. J. Dairy Res., 14(3): 340-353.

ISO, 2006. Animal and Vegetable Fats and OilsDetermination of Anisidine Value. ISO 6885: 2006(E). International Standard Organization, Switzerland.

Jain, R., K.C. Jindal and C.S. Patil, 2007. Pharmaceutical compositions containing long chain fatty acids as excipients as well as process for manufacturing the same. WO 2007/122636A1.

Kassis, A.N., 2008. Evaluation of cholesterol-lowering and antioxidant properties of sugar cane policosanols in hamsters and humans. Ph.D. Thesis, School of Dietetics and Human Nutrition, McGill University, Montreal, Canada.

Khatoon, S., R.G.R. Raja and A.G.G. Krishna, 2010. Physicochemical characteristics and composition of Indian soybean oil deodorizer distillate and the recovery of phytosterols. J. Am. Oil Chem. Soc., 87(3): 321-326.

Lewis, J., 2001. Process for the Production of Tocotrienol. US Patent 6,838,104.

Liu, D., J. Shi, L.R. Posada, Y. Kakuda and S.J. Xue, 2008. Separating tocotrienol from palm oil by molecular distillation. Food Rev. Int., 24(4): 376-391.
Loganathan, R., K.R. Selvaduray, A. Radhakrishnan and K. Nesaretnam, 2009. Palm oil rich in health promoting phytonutrients. Palm Oil Develop., 50: 16-25.

Mahendra, K., Y.L.N. Murthy, C.V.N. Rao and B.M. Krishna, 2011. Determination of ubiquinone Q10 (coenzyme Q10) and its synthesis related impurities by High Performance Liquid Chromatography (HPLC) and Mass Spectrometry (MS). Int. J. Pharma Tech. Res., 3(3): 1467-1477.

Mendez, E., M. Blanco, A. Laguna and E. Garcia, 2003. Isolation and characterization of a mixture of higher primary aliphatic alcohols of high molecular weight from henequen (Agave furcroydes L.) wax. Revista CENIC Ciencias Químicas, 34(1): 35-38.

Nandi, S., G. Sarbani and S. Gosh, 2008. Lipase catalyzed synthesis of neutral glyserides rich in micronutrients from rice bran oil fatty acids distillate. J. Oleo Sci., 57(11): 599-603.

Nang, H.L.L., N.S.A. Wafti and C.Y. May, 2009. Palm Fatty Acid Distillate. MPOB No. 471, MPOB Information Series.

Newmark, H.L., 1997. Squalene, olive oil and cancer risk: A review and hypothesis. Cancer Epidemiol. Biomarker Prev., 6(12): 1101-1103.

Ng, M.H., Y.M. Chao, A.H. Ma, C.H. Choah and M.A. Hashim. 2004. Separation vitamin E (tocopherol, tocotrienol and tocomonoenal) in palm oil. Lipids, 39: 1031-1035.

Packer, L., S.U. Weber and G. Rimbach, 2001. Molecular aspects of a-tocotrienol antioxidant action and cell signalling. J. Nutr., 131(2): 369S-373S.

Piiro n V., D.G. Lindsay, T.A. Mieyyinen, J. Toivo and A.M. Lampi, 2000. Plant sterol: Biosynthesis, biological function and their importance to human nutrition. J. Sci. Food Agric., 80(7): 939-966.

Posada, L.R., J. Shi, Y. Kakuda and S.J. Xue, 2007.Extraction of tocotrienols from palm fatty acid distillates using molecular distillation. J. Separ. Purif. Technol., 57(2): 220-229.

Prakash, I. and G.E. DuBois, 2007. High sweetener composition with long-chain primary aliphatic saturated alcohol and compositions sweetened therewith. US 20070134390A1.

Puah, C.W., C.Y. May, M. Ahngan and C.C. Hock, 2004. Degumming and bleaching: Effect on selected constituents of palm oil. J.Oil Palm Res., 16: 57-63.

Rakmi, A.R. and T. Herawan, 2000. Properties of biosurfactant enzymatically prepared from fructose and palm fatty acid. J. Oil Palm Res., 12(1): 117-122.

Serbinova, E.A. and L. Packer, 1994. Antioxidant properties of $\alpha$ - tocopherol and $\alpha$-tocotrienol. Methods Enzymol., 234: 354-366. 
Somaiya, S.S., S. Srivastava, S. Ghah and N. Mulik, 2010. A method of obtaining policosanols from natural material. World Int. Property Orgniz., WO 2010/103549 A2.

Taşan, M., B. Bilgin, Ü. Geçgel and A.Ş. Demirci, 2006. Phytosterols as functional food ingredients. J. Tekirdag Agric. Faculty, 3(2): 153-159.

Theriault, A., J.T. Chao, Q. Wang, A. Gapor and K. Adeli, 1999. Tocotrienol: A review of its therapeutic potential. Clin. Biochem., 32(5): 309-319.
Wan, J., W. Zhang, B. Jiang, Y. Guo and C. Hu, 2008. Separation of individual to copherols from soybean distillate by low pressure column chromatography. J. Am. Oil Chem. Soc., 85(4): 331-338.

Winkle-Moser, J.K. and S.F. Vaughn, 2009. Antioxidant activity of phytochemiclas from ditillers dried grain oils. J. Am. Oil Chem. Soc., 86(11): 1073-1082. 